\title{
つくばエクスプレス開業が周辺住民の交通行動に与えた影響* Effect of Tsukuba Express opening on travel behavior of resident ${ }^{*}$
}

\author{
岡本直久 $* * \cdot 川$ 川田真理絵 $* * * \cdot$ 石田東生 $* * \cdot$ 堤盛人 $* *$ ・谷口綾子 $* * \cdot$ 諸田恵士 $* * * *$
}

\section{1.はじめに}

\section{(1) 研究の背景}

2005年8月 24日、つくば市と秋葉原を結ぶ「つく ばエクスプレス（以下:TX）」が開業した。TX開 業以前、千葉県北西部および茨城県南地域の住民に とって、東京方面へ移動する公共交通はJR常磐線と 高速バスであった。TXが開通した結果、東京方面 の移動にかかる所要時間が大幅に短縮された。つく ば市中心から東京駅を結ぶ高速バスの所要時間は平 均 100 分程度であったが、TXを利用すると最短 45 分 となり、半分以下に短縮されたことになる。さらに、 鉄道利用により旅客を大量に輸送でき、定時性も確 保されることから、当該地域における東京方面への 移動性は大きく改善されたといえる。

このような地域の交通体系に大きな変化を与える 鉄道や道路建設プロジェクトに対して、プロジェク 卜終了後において地域の公共交通網の変化や地域住 民の交通行動の変化を分析し、プロジェクトの効果 や影響を検証することは極めて重要である。そこで 得られる結果を今後の交通計画に生かしていくため には、プロジェクト前後における地域の交通体系変 化を精度高く捉えることが重要な課題となる。

新しい交通体系の導入による影響や効果を計測す る方法の一つに、交通行動の変化を動的に考察する パネル調査が挙げられる。パネル調查は、同じ回答 者に対して時間をおいて繰り返し調査を行う調査方 法のことであり、回答者を特定するこによって、時 間の経過を考慮した物事の変化を把握することが可 能である。回答者個人に関するプロジェクト前後の 様々な変化を考慮することで、その変化の因果関係 を明らかにすることができる。また、その変化を個 人単位で定量的に把握することができ、プロジェク トの効果や影響を精度よく分析することができる。

* キーワーズ : 鉄道新線、行動変化、アクセス手段選 択モデル

** 正員 工博 筑波大学システム情報工学研究科

（テ305-0001 つくば市天王台 E-mail:

okamoto@sk.tsukuba.ac.jp)

*** 正員 修士 (環境科学) 株式会社長大（言 114-0013 東京都北区東田端2-1-3 E-mail:kawadam@chodai.co.jp)

**** 正員 国土政策総合研究所 道路研究室

\section{(2) 研究対象地域}

本研究で対象とする地域は、TX沿線に位置する つくば市とその周辺地域である。これらの地域は、 TX開業に伴って、路線バスの再編や駅の新設・道 路整備などが行われ、地域内の交通体系が大きく変 化している。例えば、市内に駅が新設されることで、 住民が駅まで移動する際のアクセス性が格段に向上 していると考えられる。このことから、対象地域の 住民が移動する際の環境が大きく変化していること が予想される。

これらの地域では、日常生活における自動車分担 率が79. $0 \%{ }^{1)}$ である。平成 10 年の東京都市圈パーソ ントリップ調査によると、東京都市圈の自動車分担 率は40.9\%であり、その值と比較すると、対象地域 の自動車利用率は極端に高い。一般的に、自動車の 利用率が高い要因として、公共交通網の利便性が低 く、自動車の代替手段がそしいために自動車利用が 促進されることが挙げられる。自動車の利用が増え ると、さらに公共交通の利用が減少し、利便性が低 下していくという悪循環が起こっている。

\section{(3) 研究の目的}

TX開業に伴って、駅と居住地域との距離が短縮 されたり、市内の路線バスが整備されたりすること で、周辺住民が路線バスを利用できたり、自転車を 利用できたりする機会が増加することが考えられる。 それとともに、周辺住民が多様な交通手段を選択で きる環境が整ってきたと予想される。そこで本研究 では、はじめに対象地域における交通体系の変化に 伴う周辺住民の交通行動の変化を整理する。さらに、 一人ひとりの交通に対する意識変化とそれに伴った 行動変化を捉え、TX開業が対象地域にもたらした 効果と影響を整理することを目的としている。

本研究では、TX開業前後において、交通実態調 査をパネル形式で行い、得られたデータに基づいて、 TX開業前後の交通行動における2時点間の差異を把 握する。

\section{(4) 研究の特徵}

鉄道の新線開業や延伸に関連した近年のパネル調 査・研究事例は、近年では、千葉都市モノレールを対 象とした毛利ら $(1995)^{2)}$ や京都市地下鉄を対象とし た西井ら $(1999)^{3)}$ など、多くの事例が見られる。本研 究の特徴として、(1)パネルデータを用いた開業前後の 比較を行っている点、(2)都市内の交通体系の変化にも 
焦点をあて、鉄道建設に伴う交通サービスの変化も含 んだ影響を捉えようとする点に特徵があると言える。

\section{2. 調査概要}

\section{(1)調査概要}

2005 年 7 月 30 （日）に実施したTX開業前交通実 態調查(以下、本文中では事前調查とする)に続いて、 $\mathrm{TX}$ の開業を挟んでほぼ 1 年後の 2006 年 7 月に、TX 開業後交通実態調査（以下、事後調査とする）を実 施した。なお、この調査は、2005 年と 2006 年に筑 波大学都市交通研究室と国土技術政策総合研究所道 路研究室が共同で実施したものである。本調査で得

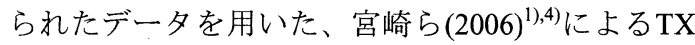
開業後の交通行動変容の可能性に関する分析が既存 研究として挙げられる。本研究の調査概要では、事

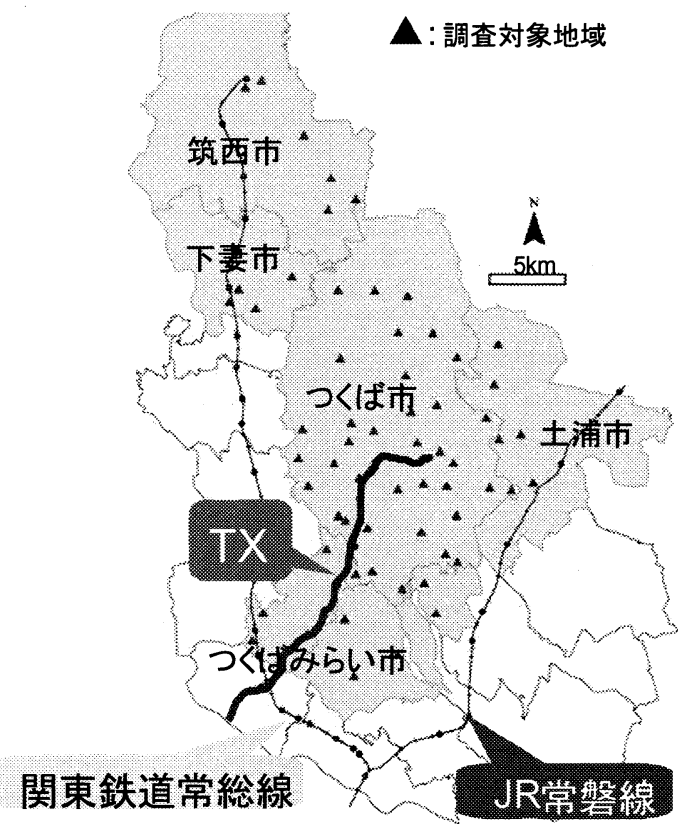

図-1 調查対象地域

表 -1 交通実態調査概要

\begin{tabular}{|c|c|}
\hline 調査期間 & $\begin{array}{l}\text { 事前調查: 2005年7月30日(土) 8月7日(日) } \\
\text { 事後調査:2006年7月15日(土) 7月23日(日) } \\
\end{array}$ \\
\hline 調査方法 & 訪問留置·訪問回収 \\
\hline 対象地域 & $\begin{array}{r}\text { つくば市及び周辺地域 } \\
\text { (土浦市·つくばみらい市·筑西市·下妻市) }\end{array}$ \\
\hline 調査内容 & $\begin{array}{c}\text { 交通実態調査 } \\
\text { 及び交通に対誡る意識調査 }\end{array}$ \\
\hline 調査項目 & 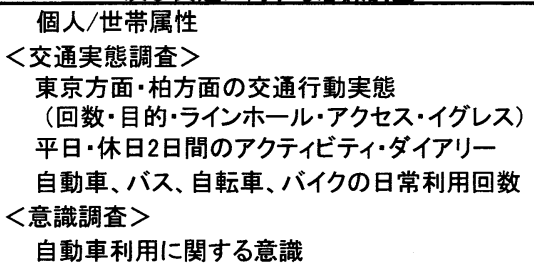 \\
\hline
\end{tabular}

後調査については詳しく明記するが、事前調査につ いては既存研究を参照いただきたい。事前・事後調 查の概要を表-1に示す。

\section{(2)事後調查の実施}

事後調査は、事前調査と同一の対象者に、同様の 質問形式で調查を行うパネル形式で実施した。調査 方法として、調查員が各世帯を訪問して調查票を配 布し、後日に再度訪問して調查票を回収する、訪問 留置・訪問回収方法を用いた。調查結果を表-2 に示 した。事前調査では、調查対象 1,500世帯に対して 1,067 世帯（回収率 $71.1 \%$ ）の回答を得た。事後調 查では、972 の調査対象世帯に対して、666 世帯

(回収率 $68.5 \%$ ) の回答を得ている。なお、事前調 査の回収した世帯数と事後調査で、対象とした世帯 数が違っているが、これは、事前・事後調查間に TFP調査 ${ }^{1)}$ を行い、その際に調查に協力していただ けなかった世帯の分が除かれたためである。TFP調 査の詳しい内容・結果については宮崎ら $(2006)^{1)}$ を 参照いただきたい。表-3 は、個人べースでの調査実 施結果を示している。事後調査では、1,716 人に対 して 1,070 人（回収率 $62.4 \%$ ）の回答が得られた。 事前、事後を通してすべての調査に回答してくれた パネルとしての人数は 819 人であった。

調査で得たパネルデータの属性を、図-2に性別、 図-3に年齢構成を示した。性別を見ると、実際の調 查対象地域の男女比とパネルデータの男女比はどち らもほぼ 1:1 であり、データはこの地域を代表し ているといえる。一方で、年齢構成を見ると、40 代および 50 代のデータが実際よりも過大であり、 20 代から 30 代のデータは少なくなっていることが

表 -2 調査実施結果（世帯）

\begin{tabular}{lcc|cc}
\hline & \multicolumn{3}{c|}{ 事前調査 } & \multicolumn{2}{c}{ 事後調査 } \\
\hline 世帯ベース & (世帯) & $(\%)$ & (世帯) & $(\%)$ \\
\hline 調查対象 & 1500 & & 972 & \\
配布 & 1485 & & 713 & \\
回収 & 1067 & $71.1 \%$ & 666 & $68.5 \%$ \\
\hline
\end{tabular}

表 -3 調査実施結果（個人）

\begin{tabular}{lcc|c}
\hline & \multicolumn{2}{c|}{ 事後調査 } & パネル \\
\hline 個人ベース & $($ 人) & $(\%)$ & $($ 人 $)$ \\
調査対象 & 1716 & & \\
配布 & 1354 & & \\
回収 & 1070 & $62.4 \%$ & 819 \\
\hline
\end{tabular}

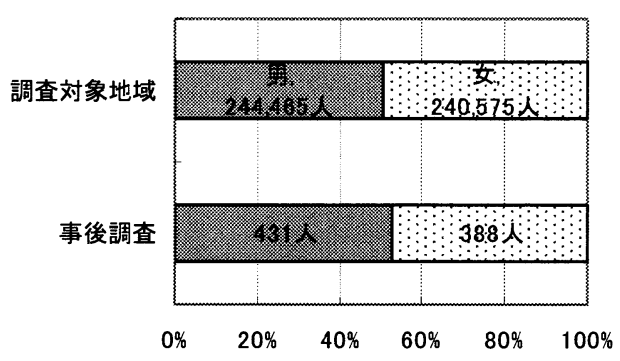

図ー2 対象地域とパネルデータの性別 
わかる。20 代から 30 代の回答割合が少ない理由と して、アクティビティダイアリー調査の回答が難し く、回答に時間がかかるため、時間的な余裕がない 世帯では回答が得にくくなったと考えられる。

\section{3. 交通実態の変化}

\section{(1) 発生量変化}

1 ケ月の東京方面への発生交通量を表-4 に示す。 事前調査と事後調査で、東京方面への発生トリップ が 0 だった回答を含めた場合(グロストリップ)、除 いた場合(ネットトリップ)のそれぞれで、発生トリ ップ数は TX 開業後、統計的に有意な差は見られな い。したがって、TX 開業により東京方面へのトリ ップが変化したとはいえない結果となった。他地域 からの転居者増等によって、集計量として調査対象 地域から東京方面への移動量は増加していることが 想像できるが、本データのサンプルでは、TX 開業 前後の発生量の変化は確認できなかった。

しかしながら、東京方面トリップ数変化の要因に ついて、、TX 利用の有無と最寄の TX 駅までの距 離に関しては、トリップ数の違いが確認できた。 図-4には TX を利用しない人の東京方面移動トリッ プの変化、図-5には TX を利用する人の東京方面移 動トリップの変化を示す。図-4 と図-5 を比較すると、 東京方面へのトリップが増加しているのは TX を利 用している人の方が多いことが確認できる。また、 図-4 中の各線は、住民の居住地域からそれぞれ最寄 の TX 駅までの距離ごとに分類して示しているが、 居住地から最寄駅までの距離が近いほど東京方面へ のトリップが増加している。このことから、TX 駅 の近くに居住する人が TX を利用することによって、

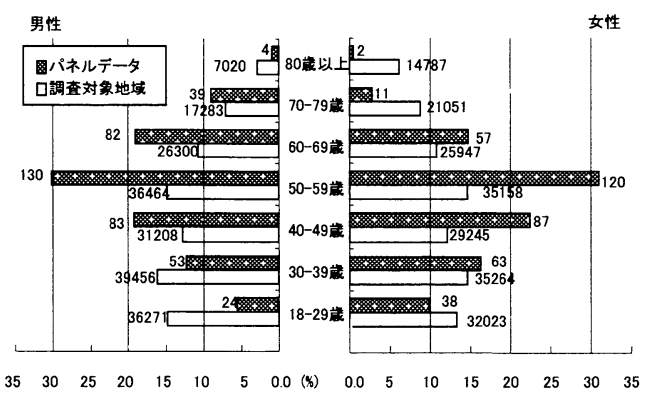

図一3 対象地域とパネルデータの年齢構成

表 -4 東京方面移動トリップの変化

\begin{tabular}{c|c|c|c|c}
\hline & \multicolumn{2}{|c|}{ ネットトツプ } & \multicolumn{2}{c}{ グロストリップ } \\
\hline & 開業前 & 開業後 & 開業前 & 開業後 \\
\hline 回/月 & 3.25 & 3.11 & 2.19 & 2.10 \\
\hline $\mathrm{t}$ t値 & \multicolumn{2}{|c|}{-0.739} & \multicolumn{2}{|c}{-0.739} \\
\hline $\mathrm{N}$ & \multicolumn{2}{|c|}{516} & \multicolumn{2}{c}{767} \\
\hline
\end{tabular}

東京方面へのトリップが増加傾向であることがわか る。

\section{(2) 交通分担率の変化}

東京方面への利用交通機関の分担率を図-6に示し た。TX開業後では TXを利用する割合が $50 \%$ 以上 を占めるようになった。逆に、常磐線の利用は、 $71.1 \%$ から $29.9 \%$ に $40 \%$ 程度减少し、高速バスの利 用は、15.5\%から $2.2 \%$ と $13 \%$ 减少している。一方、 自動車利用の割合はそれほど変化していない。

また図-7 は、TX 開業前では高速バスのバス停留 所と常磐線の各駅、TX 開業後では TX の各駅も含 めて、駅およびバス停留所までのアクセス手段を示 している。徒歩をアクセス手段として選択している 人の割合は高速バスで多いが、これは高速バス停留 所が竹園、並木地区に見られる住宅街に近接してい

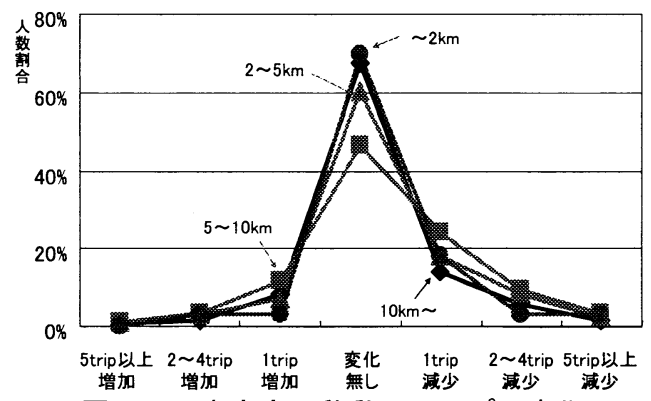

図-4 東京方面移動トリップの変化 (TX 以外利用者)

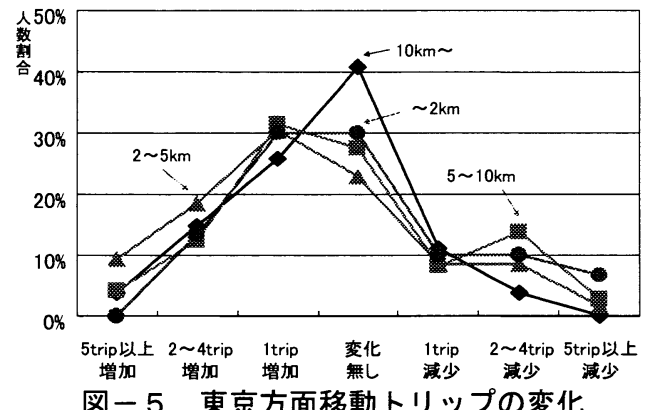

(TX 利用者)

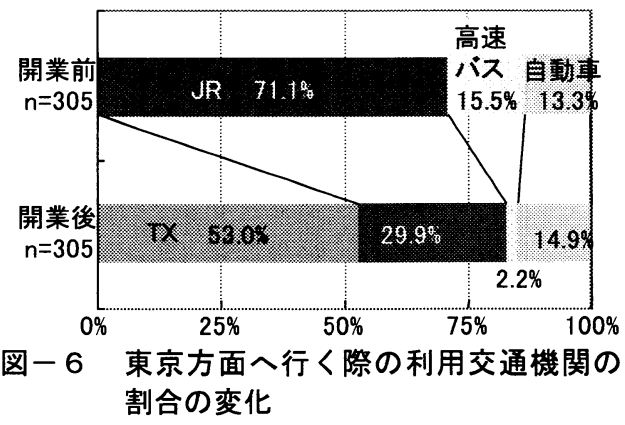


ることが考えられる。また、路線バスに着目すると、 常磐線および高速バスへのアクセス手段として路線 バスの利用割合が増加していることがわかる。この 要因のひとつとして TXの終着駅と高速バスの停留 所を兼ねている「つくばセンター」に向かう路線バ スの運行数が増便されたことが考えられる。

\section{4.アクセス手段選択モデルによる比較}

\section{(1) モデルの構築}

対象地域の各出発地から東京方面に移動する際に、 どのようなアクセス交通手段を選択して、幹線交通 機関の駅や停留所まで移動しているのかを非集計モ デルを用いて推定した。事前調查と事後調査の 2 時 点のモデルを比較することで、アクセス手段を選択 する要因がどのように変化しているのかを考察する。

説明変数は、各駅までの所要時間および費用、路 線バスの本数、定数項（徒歩）、定数項（二輪車）、 定数項（路線バス）とする。

選択肢となる交通手段は、「徒歩」「二輪車」

「路線バス」「自動車」である。実際にアクセスし た駅までのアクセス交通手段の選択モデルを構築す る。

\section{(2) モデル推定結果}

モデルの推定結果を表-5 に示す。2つのモデルを 比較すると、次のことがわかる。(1)両時点のモデル はパラメータの符号、尤度比、的中率ともにおおむ ね良好である。(2)TX 開業後、所要時間のパラメー

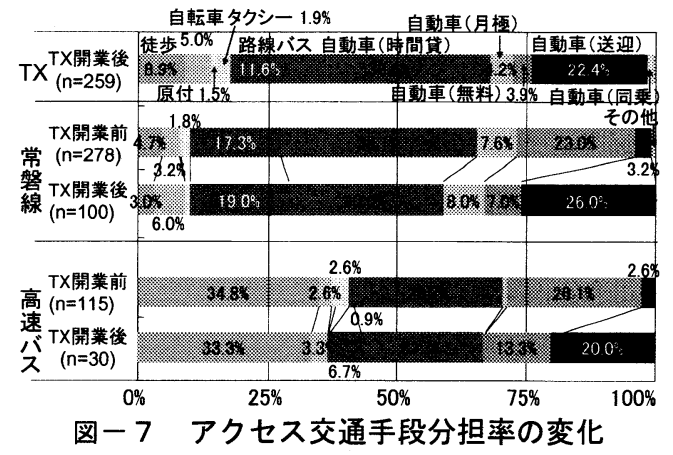

表一5 アクセス交通手段選択モデル推定結果

\begin{tabular}{ll|ll|ll}
\hline \multirow{2}{*}{} & & \multicolumn{2}{|c|}{ TX開業前 } & \multicolumn{2}{c}{ TX開莱後 } \\
\cline { 3 - 6 } & & parameter & t-value & parameter & t-value \\
\hline 所要時間(分) & [共通] & -0.01476 & -1.71 & -0.05946 & -5.59 \\
費用(円) & [共通] & -0.001313 & -0.365 & -0.001264 & -1.34 \\
バス本数(本/日) & [バス] & 0.07358 & 3.83 & 0.03786 & 2.99 \\
定数項 & [徒歩] & -2.018 & -1.19 & 0.1740 & 0.235 \\
定数項 & [二輪] & -2.869 & -1.80 & -2.306 & -3.86 \\
定数項 & [バス] & -3.449 & -5.64 & -2.375 & -6.98 \\
\hline サンプル数 & & \multicolumn{2}{|c|}{277} & \multicolumn{2}{|c}{277} \\
尤度比 & & \multicolumn{2}{|c|}{0.5317} & \multicolumn{2}{c}{0.4418} \\
的中率(\%) & \multicolumn{2}{|c|}{78.98} & \multicolumn{2}{c}{76.17} \\
時間評価値(円/分) & \multicolumn{2}{|c|}{11.24} & \multicolumn{2}{c}{47.05} \\
\hline
\end{tabular}

タの $\mathrm{t}$ 值が大きく向上しているとともに、費用のパ ラメータの $\mathrm{t}$ 值も $10 \%$ に満たないものの、大きく 向上している。

所要時間のパラメータの $\mathrm{t}$ 值が、 $\mathrm{TX}$ 開業後に大 きくなっていることから、TX 開業後にアクセス手 段を選択する際に、所要時間を重視する傾向になっ ていることがわかる。TX 開業前の対象地域では、 $20 \mathrm{~km}$ 以上離れた既存 JR 駅まで行かなければならず、 アクセスで選択できる交通手段は車か、バスだけで あった。そのため、交通手段ごとの所要時間を考慮 して手段を選択できるほど交通サービスが行き届い ていなかった。

しかしながら、これは、TX が開通することで、 駅へのアクセス手段に新しい選択手段として自転車 や徒歩が増えて、交通サービスレベルが向上したと によると考えられる。

\section{5.自動車に対する意識と交通手段選択の 差異}

対象地域の住民は、日常の移動手段を自動車に依 存している状態であることから、路線バスや徒歩、 自転車などの他の交通手段を利用することは困難で

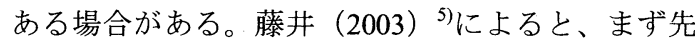
に、自動車を利用することを控えようとする「行動 意図」が形成されることによって、自動車以外の手 段を利用することが可能となるとしている。「行動 意図」とは、「〜しようと思う」「〜するつもり だ」という形の心理要因であり、実際に行動すると きの「動機」と言い換えられる。すなわち、個人の 行動が変わるときには、「行動意図」が心理的に形 成されることが必要条件となる。TX開業前後の交 通実態調査では、「自動車利用をできるだけ控えよ うと思っているかどうか」という質問に対し、「そ う思う」〜「そう思わない」の 5 段階尺度で質問し ている。この回答を「自動車利用抑制意図」と定義 する。ここでは、TX開業前後での回答の尺度と、 交通行動の特性との関係について分析を行った。自 動車利用抑制意図の強さの段階別に、「意図が弱い （意図弱）」「意図が中間の人（意図中）」「意図 が強い人（意図強）」、とセグメントを設定し直し て、適用した。

$\mathrm{TX}$ 開業前後における東京方面への移動の際に利 用する交通機関のアクセス交通手段選択モデルにつ いて、所要時間変数を自動車利用抑制意図別に分離 して推定した。そして、アクセス交通手段選択と自 動車利用抑制意図の関係について分析を行なった。

\section{(1) モデルの構築}

交通機関選択の説明変数には、設定した自動車利 用抑制意図のセグメントごとにおけるアクセス所要 時間、費用、バス本数、の 3 つと、徒歩、二輪車、 路線バスの 3 つの定数項を用いた。選択する交通手 段は、「徒歩」「二輪車」「路線バス」「自動車」 
の 4 つを設定している。

\section{(2) モデル推定結果}

2 時点それぞれの分析結果を表-6 に示す。これよ り、次のことがわかる。

(1) モデルはパラメータの符号、 $\mathrm{t}$ 值及びモデル の説明力を示す尤度比、的中率ともにおおむ ね良好である。

(2) 所要時間のパラメータに対する $\mathrm{t}$ 值が、 $\mathrm{TX}$ 開業後にはより有意な值になっている。

(3)「所要時間（意図弱）」と「所要時間（意図 強）」のパラメータの大きさは、TX 開業前 に比べて、TX 開業後に差が大きくなってい る。

(3)の結果から、TX 開業後において、自動車利用 抑制意図の弱い人ほど、アクセス手段を選択する際 に、移動における所要時間に重点をおいて交通手段 を選択している傾向にあると考えられる。つくば市 のように渋滞の少ない地域において、高速で移動で き、ドア to ドアで移動できる自動車が、最も所要 時間が短いと考えられる。よって、自動車利用抑制 意図が弱い人は、自動車を選択する傾向が強いと解 釈することができる。逆に、自動車利用抑制意図が 強い人がアクセス手段を選択する際は、移動の所要 時間の短さにこだわらずに選択している傾向がある と考えられ、自動車以外の手段（公共交通、自転車、 徒歩）などを選択する傾向にあると推測できる。こ の地域では、住民が選択する交通手段において、自 動車か、自動車以外かという差がより顕著に表れて きたといえるだろう。自動車利用を抑制する意図が 低い住民の詳しい属性や、要因などの、詳しい分析 が必要である。

\section{6. まとめ}

\section{（1）交通実態変化について}

TX 開業が直接的にもたらした交通行動への影響 について分析を行った結果、要因分析において、特
に居住地と駅との位置関係によって、東京方面への 移動トリップ数が大きく変化していることが明らか になった。

\section{（2）都市内利用交通手段について}

自動車利用抑制意図の強さによって、アクセス交 通を選択する行動に違いがあることが統計的に説明 できた。この結果は、当該地域における TFP 等の モビリティ・マネジメント実施に当たっての有益な 情報であると考える。無論、自動車利用抑制意図の 違いがどのような要因によって生じるかの分析を深 める等の課題は残されているが、抑制意図が強い層 への積極的な働きかけや、抑制意図の低い層を向上 させる取り組み等を考察し、効率的な自動車抑制を 図ることが出来る可能性がある。

なお、本研究のほとんどの論点は、2 時点間のモ デル比較に基づく議論であり、個々人の行動変化に ついては、言及していない。この点は、今後の課題 である。

参考文献

1) 宮崎文生, 石田東生, 岡本直久, 堤 盛人, 谷口綾子 （2006）：効果的な T F P 対象者の設定に関する研 究〜つくば市および周辺地域を対象として〜,土木計 画学研究発表会・講演集,33,CD.ROM.

2)毛利雄一,中野敦,原田昇(1995)：モノレール開業に伴 う事前・事後調査の活用に関する研究.調査方法と交 通需要予測手法の改善,土木計画学研究 ・論文 集,12,pp633-642

3) 西井和夫,酒井 弘,西野 至,浅野智弥 (1999) : 京都 市地下鉄開通に伴う交通行動変化に関するパネル調 查,士木計画学研究・講演集,22,pp687-690.

4) 宮崎文生（2006）：つくば市および周辺地域におけ る交通実態調査と TX 開業後の交通行動変化の可能 性について,平成 17 年度筑波大学システム情報工学 研究科修士論文

5）藤井聡（2003）：『社会的ジレンマの処方箋』,ナカ ニシヤ出版.

\section{表一 6 自動車利用抑制意図別アクセス交通 手段選択モデル推定結果}

\begin{tabular}{|c|c|c|c|c|c|}
\hline & \multicolumn{2}{|c|}{ TX開業前 } & \multicolumn{2}{|c|}{ TX開業後 } \\
\hline & & parameter & t-value & parameter & $t$-value \\
\hline 所要時間 (意図弱)(分) & [共通] & -0.01410 & -2.07 & -0.07926 & -4.77 \\
\hline 所要時間 (意図中) (分) & [共通] & -0.02393 & -1.58 & -0.06988 & -3.28 \\
\hline 所要時間 (意図強)(分) & [共通] & -0.008407 & -1.57 & -0.04852 & -4.58 \\
\hline 費用 (円) & [共通] & 0.001512 & 1.43 & -0.001253 & -1.33 \\
\hline 自転車保有ダミー & [二鈴] & 0.3554 & 1.50 & 0.2421 & 1.38 \\
\hline ハスス本数(本/日) & [ハiス] & 0.05896 & 3.77 & 0.03840 & 3.02 \\
\hline 定数項 & [徒歩] & 0.04046 & 0.0553 & 0.2086 & 0.282 \\
\hline 定数項 & [二㢵] & -3.099 & -2.76 & -3.084 & -3.54 \\
\hline 定数項 & [バス] & -2.667 & -7.49 & -2.351 & -6.89 \\
\hline $\begin{array}{l}\text { サンプル数 } \\
\text { 尤度比 } \\
\text { 的中率(\%) }\end{array}$ & & $\begin{array}{r}27 \\
0.39 \\
68 .\end{array}$ & & $\begin{array}{c}27 \\
0.45 \\
76 .\end{array}$ & \\
\hline
\end{tabular}


つくばエクスプレス開業が周辺住民の交通行動に与えた影響

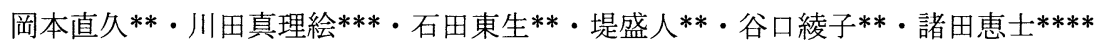

本論文では、つくばエクスプレスの周辺地域における住民の交通行動の変化と、交通手段に対寸る意識の変化 を把握し、つくばエクスプレス開業が住民に与えた影響を把握することを目的としている。2005年8月24日、つく ば市と秋葉原を結ぶつくばエクスプレスが開業し、つくば市とその周辺地域では、路線バスの再編や駅の新設・ 道路整備などが行われ、地域内の交通体系が大きく変化したことが期待される。

結果として、駅などの幹線公共交通へのアクセス手段について、つくばエクスプレス開業前に比べて住民がよ り合理的に交通手段を選択する傾向が示唆され、アクセス手段の交通サービスレベルが変化していることが伺え た。

\title{
Effect of Tsukuba Express Opening on Travel Behavior of Resident*
}

By Naohisa OKAMOTO, Marie KAWADA, Huruo ISHIDA, Morito TSUTSUMI, Ayako TANIGUCHI, and Keishi MOROTA Tsukuba Express has started since 2005, which connects Tsukuba city and Tokyo metropolitan. According with the Tsukuba Express railway project, the transportation system has been greatly changed in Tsukuba city and surrounding area.

The object of this paper is to understand the impact of Tsukuba Express railway project in terms of the actual travel pattem and the behavior to the transportation of the residents in surrounding areas before and after operating Tsukuba Express. The results showed that the level of transportation service improved, which leads the residents choose the transportation modes rationally. 